DEMOGRAPHIC RESEARCH

VOLUME 34, ARTICLE 24, PAGES 689-704 PUBLISHED 19 APRIL 2016

http://www.demographic-research.org/Volumes/Vol34/24/

DOI: 10.4054/DemRes.2016.34.24

Descriptive Finding

\title{
Intergenerational money and time transfers by gender in Spain: \\ Who are the actual dependents?
}

\section{Elisenda Rentería}

Rosario Scandurra

Guadalupe Souto

Concepció Patxot

(c) 2016 Rentería, Scandurra, Souto \& Patxot.

This open-access work is published under the terms of the Creative Commons Attribution NonCommercial License 2.0 Germany, which permits use, reproduction \& distribution in any medium for non-commercial purposes, provided the original author(s) and source are given credit.

See http://creativecommons.org/licenses/by-nc/2.0/de/ 


\section{Table of Contents}

$\begin{array}{lll}1 & \text { Introduction } & 690\end{array}$

$2 \quad$ Data and methods 691

$2.1 \quad$ Construction of economic profiles by sex 692

2.2 Time profile construction and time monetization 692

$3 \quad$ Results 693

4 Conclusion $\quad 699$

$5 \quad$ Acknowledgements $\quad 699$

$\begin{array}{ll}\text { References } & 701\end{array}$ 


\title{
Intergenerational money and time transfers by gender in Spain: Who are the actual dependents?
}

\author{
Elisenda Rentería ${ }^{1}$ \\ Rosario Scandurra ${ }^{2}$ \\ Guadalupe Souto $^{3}$ \\ Concepció Patxot ${ }^{4}$
}

\begin{abstract}
BACKGROUND

The analysis of intergenerational transfers can shed light on the interaction between population age structure and welfare. Nevertheless, a thorough examination of this issue requires consideration of both monetary (market) and time (non-market) transfers.
\end{abstract}

\section{OBJECTIVE}

We analyse market and non-market production, consumption, and transfers by age and gender for Spain from 2009-2010 using National (Time) Transfer Accounts (NTA and NTTA) methodology.

\section{METHODS}

Using National Accounts, microdata from different surveys, and the Time Use Survey, we estimate age and sex-specific profiles of monetary and time production and consumption for Spain. Consequently, a surplus or deficit and the resulting transfers are obtained.

\section{RESULTS}

We observe higher labour income for men with respect to women throughout the age profile. Nevertheless, women spend more hours in total (market and non-market activities) than men. This division drives an asymmetry in private transfers. While men are net donors of money to other age groups during their working life, women are net

\footnotetext{
${ }^{1}$ Universitat de Barcelona, Department of Economic Theory, Barcelona, Spain. Corresponding author. E-Mail: elisenda.renteria@ub.edu.

${ }^{2}$ Universitat de Barcelona, Department of Sociology, Barcelona, Spain. E-Mail: rosario.scandurra@ub.edu.

${ }^{3}$ Universitat Autònoma de Barcelona, Department of Applied Economics, Barcelona, Spain. E-Mail: guadalupe.souto@uab.cat.

${ }^{4}$ Universitat de Barcelona, Department of Economic Theory and Xarxa de Referència en Economia i Polítiques Socials, Barcelona, Spain. E-Mail: cio.patxot@ub.edu.
} 
donors of time to other household members (mainly children and their partners) over their lives.

\section{CONCLUSION}

The inclusion of the non-market economy in the analysis of intergenerational transfers is crucial to observe real inequalities between genders throughout the life cycle. This challenges the 'economic dependency' of women based on a market economy. The results suggest that the public sector in Spain should reinforce policies that take into account women's contribution to the welfare of other population groups, and call for policies that reconcile professional and family obligations.

\section{Introduction}

The analysis of intergenerational transfers has contributed to the understanding of the interaction between population age structure and welfare. This topic has been studied for a long time (Willis 1988; Lee, Parish, and Willis 1994; Albertini, Kolhi, and Vogel 2008), but the National Transfer Accounts (NTA) project (Lee and Mason 2011) takes a comprehensive description of age reallocations, including both public and private transfers and asset-based reallocations, building a generational economy account, consistent with National Accounts. Recently, following the methodology developed by Donehower (2014), non-market activities have been included in the original NTA framework (Donehower and Mejia-Guevara 2012; Zagheni and Zannella 2013; Kluge 2014; Hammer, Prskawetz, and Freund 2015; Zannella 2014; Gál, Szabóc, and Vargha 2015; Jimenez-Fontana 2015). This refers mainly to time devoted to unpaid tasks such as housework or caring for other family members, allowing a thorough analysis of generational economy accounts by gender, which is otherwise misleading. The introduction of gender extends the understanding of how transfers and age reallocation are distributed over the life cycle (Waring 1999), but also makes visible the essential contribution to the welfare system by women, who are the principal providers of care and welfare for children and dependent individuals (Anxo et al. 2007; Esping-Andersen 1999; Ferrera 1996; Giullari and Lewis 2005).

Time use literature shows that adult women, especially once they are mothers, spend more time in domestic production than men (Folbre 2004). In Europe this pattern is particularly marked in Mediterranean countries, showing a greater time gap between men and women engaged in housework (Durán 2010). "Unsupported familism" is a characteristic feature of the Southern European model (Saraceno 1997), implying scarce development of public provision of childcare and long-term care services and insufficient measures supporting work-life balance. Spain is a special case within the 
southern welfare model as it experienced an increasing and rapid shift towards a dualearner model until the financial crisis of 2008. Women's employment rate rose from $34.5 \%$ in 1992 to $53.8 \%$ in 2013 . However, having children is strongly related to a decline in female labour income, and this is mainly due to women leaving the labour market rather than temporarily interrupting their activities (Anxo et al. 2007; Naldini and Jurado 2013). Therefore, as observed in economic transfers (see Patxot et al. 2011 for Spain), non-market transfers depend strongly on the exact moment in the life cycle. For example, the number of unpaid hours of housework for women increases sharply after age 30 (Zagheni et al. 2015). Moreover, in a comparative study, Hammer, Prskawetz, and Freund (2015) observe that when summing up paid and unpaid production, only women from Spain (2002) and Slovenia (2000) produce more than men, and in the case of Spain it is due to a much higher contribution of women's housework and household care. This fosters the precarious situation of women as nonmarket workers in Spain, lacking protection and regulation (Durán 2012).

Hence, increasing access to the labour market does not necessarily imply gender equality within the household, unless an effort to balance family care is made through public policies (Lewis 2009). In Spain, welfare and market provision have not substituted women's traditional role as caregivers for children and dependent adults (Durán 2010; Lewis 2009). Therefore, consideration of age and gender when analysing economic transfers is crucial to acknowledge gender differences over the life cycle and to raise concerns about using a concept of economic dependency that only contemplates monetary factors (Brines 1994).

In this article we estimate Spanish age profiles of transfers and age reallocations of both market and non-market activities by gender, using NTA and NTTA methodology. We aim to compare gender differences in production, consumption, and transfer distribution over the life cycle. The analysis also identifies how time transfers flow between age and gender groups.

\section{Data and methods}

We rely on different datasets to construct economic transfer age profiles. We use the Household Budget Survey (EPF) to estimate private consumption profiles and the European Survey on Income and Living Conditions (EU-SILC) for income profiles. Both databases are combined to obtain private transfer profiles. Public consumption, pensions, and other social expenditure data are extracted from government statistics (MEYSS; MECD; MSSSI). National economic aggregates come from Spanish National Accounts (INE). The baseline year for all surveys and aggregates is 2009. Non-market or time profiles are constructed from Time Use Survey (TUS) 2009-2010, which 
collects time diaries where respondents report information on daily activities. As explained below, non-market activities are valued using the Structure of Earnings Survey (SES) 2010.

\subsection{Construction of economic profiles by sex}

We use NTA methodology to estimate intergenerational transfers (UN 2013). This method distributes national accounts by age, allowing estimation of economic exchanges between age groups through three institutions: government, where public transfers are made (such as payment of pensions); family, including private transfers (such as parents paying for childcare); and market, referring to asset reallocations (such as borrowing money from a bank). The basic assumption of NTA is that the difference between consumption and labour income for each age group (the so-called life cycle deficit) must be financed by the following equation:

$$
\begin{gathered}
C_{x}-Y_{x}^{l} \\
\text { Life cycle deficit }
\end{gathered} \quad \begin{gathered}
Y_{x}^{a}-S_{x} \\
\text { Asset-based reallocations }
\end{gathered} \underset{\text { Public transfers }}{T G I_{x}-T G O_{x}}+\underset{T F I_{x}-T G O_{x}}{\text { Private transfers }}
$$

where $\mathrm{C}$ is consumption, $\mathrm{Yl}$ labour income, $\mathrm{Ya}$ asset income, $\mathrm{S}$ savings, and $\mathrm{T}$ transfers, both public (TG) and private (TF). Moreover, transfers are subdivided into inflows (I) (received by individuals) and outflows (O) (paid by individuals). We estimate an age profile by sex for each of these magnitudes, using microdata or age- and sex-specific information from other sources. Profiles are adjusted to the corresponding National Accounts aggregate.

\subsection{Time profile construction and time monetization}

First, we need to define household non-market activities considered as productive. We thus follow the "third party" criterion described by Reid (1934), where household production refers to all household members' activities that could be externalised by paying a third person to perform them. This includes activities like house management, cleaning, cooking, and household members' care. In the presence of multitasking, we only contemplate the main task reported in the survey. Time production and consumption age profiles are estimated similarly to NTA profiles (Donehower 2014), considering that production must equal consumption, as it is impossible to save or borrow time. Therefore, any time surplus or deficit automatically translates into a transfer. As the time survey is a dataset of time producers, production age profile is 
estimated directly. However, consumption is not observed and certain assumptions are necessary. For children and elderly care activities, we regress production on the number of individuals of each age group, divided into young (under 18) and adult (over 18) populations. For general household management activities, time is divided evenly between household members. Time consumers from other households are assumed to have the same age distribution as consumers inside the household. Time transfers are obtained as the difference between production and consumption, being an outflow if positive and an inflow otherwise.

Finally, we need to assign a monetary value to time use to compare non-monetary with monetary transfers included in the National Accounts system (Abraham and Mackie 2005). There are two methods to value time use: opportunity cost and replacement cost. According to opportunity cost, the value of a household activity is based on the income that would be received by the person if they were doing another activity. This type of valuation is controversial because housework value depends on the person performing the task, although the task is exactly the same, and it may reproduce the same inequalities observed in the market (Chadeau 1992). We opt, then, for the replacement method as the most appropriate and far less complex, consisting of assigning to domestic tasks the average wage of a person who performs the same task in the market. Specifically, we assign the corresponding market wage to each non-market activity extracted from the SES.

\section{Results}

Figure 1 shows per capita age profiles of total hours worked - including paid and unpaid activity - by gender. As observed, women spend more hours in market and nonmarket activities than men throughout the age profile. These results are in line with previous literature based on the same survey (Gimenez-Nadal and Sevilla 2014). From ages 21 to 65, women work on average (market and non-market) 1.1 hours (16\%) more than men. For people aged 58 and more this difference increases to $43 \%$, showing that retired men reduce their paid working time without increasing their time dedicated to household work. Nevertheless, looking only at market activities, men of working age (21-65 years) dedicate 57\% more hours than women. As a consequence, women's labour income is $22 \%$ lower than men from age 23 to 32, and this gap increases to $50 \%$ from age 45 to 60 .

Hence, a high imbalance in labour market participation and earnings by gender is observed in the Spanish economy: most labour market production is done by men, while housework is still mainly done by women, despite the increase in female labour market participation. During maternity years, women show a higher amount of total 
working hours and lower labour incomes. However, this is a cross-sectional analysis that gathers women from different generations. Younger women have increased their labour participation and reduced their fertility rates, meaning that their performance at older ages might be significantly different from current older women (Nieuwenhuis, Need, and Van der Kolk 2012).

\section{Figure 1: Total working hours (market and non-market) by gender}

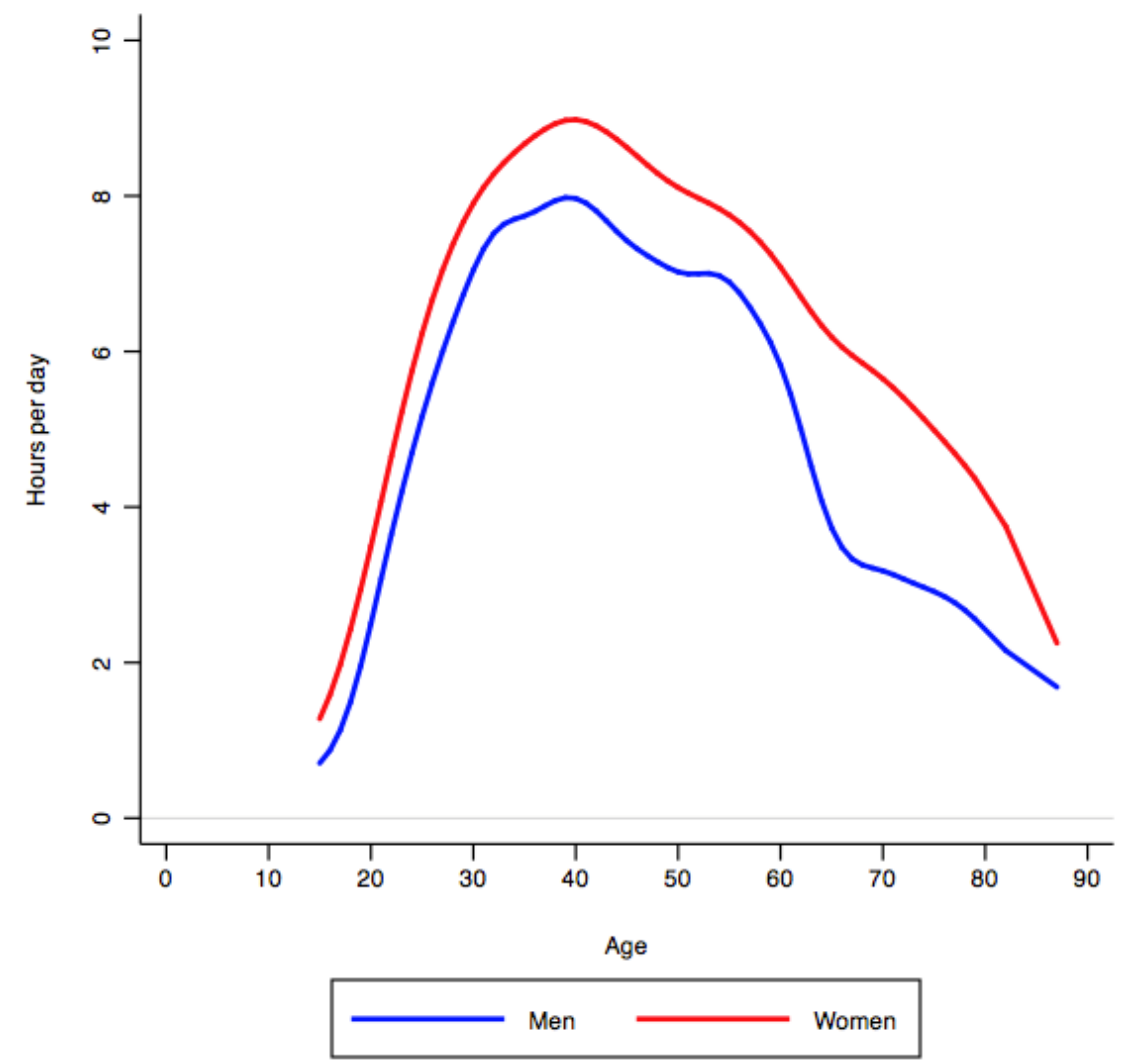

Source: Author's own calculations using TUS 2009-2010 and EU-SILC.

Figure 2 shows life cycle deficit (LCD) by gender, both monetary LCD difference between consumption and production of market activities - and non-market LCD - based on time use estimates. When consumption is higher than production, LCD 
is positive; otherwise it is negative. As observed, men start having negative market LCD earlier than women, but the reverse occurs with non-market LCD, where women show negative values when younger than men. Consumption lower than production in market activities finishes at age 62 for men and at age 54 for women. Nevertheless, negative LCD for non-market activities finishes earlier for men (age 49), while for women it continues beyond age 80. Interestingly, when total LCD (sum of both LCDs, results not shown) is considered, women start being economically dependent at age 58 (positive LCD), while this age remains constant for men at 62.

Figure 2: $\quad$ Life cycle deficit of market (NA) and non-market (household) activities (per capita)

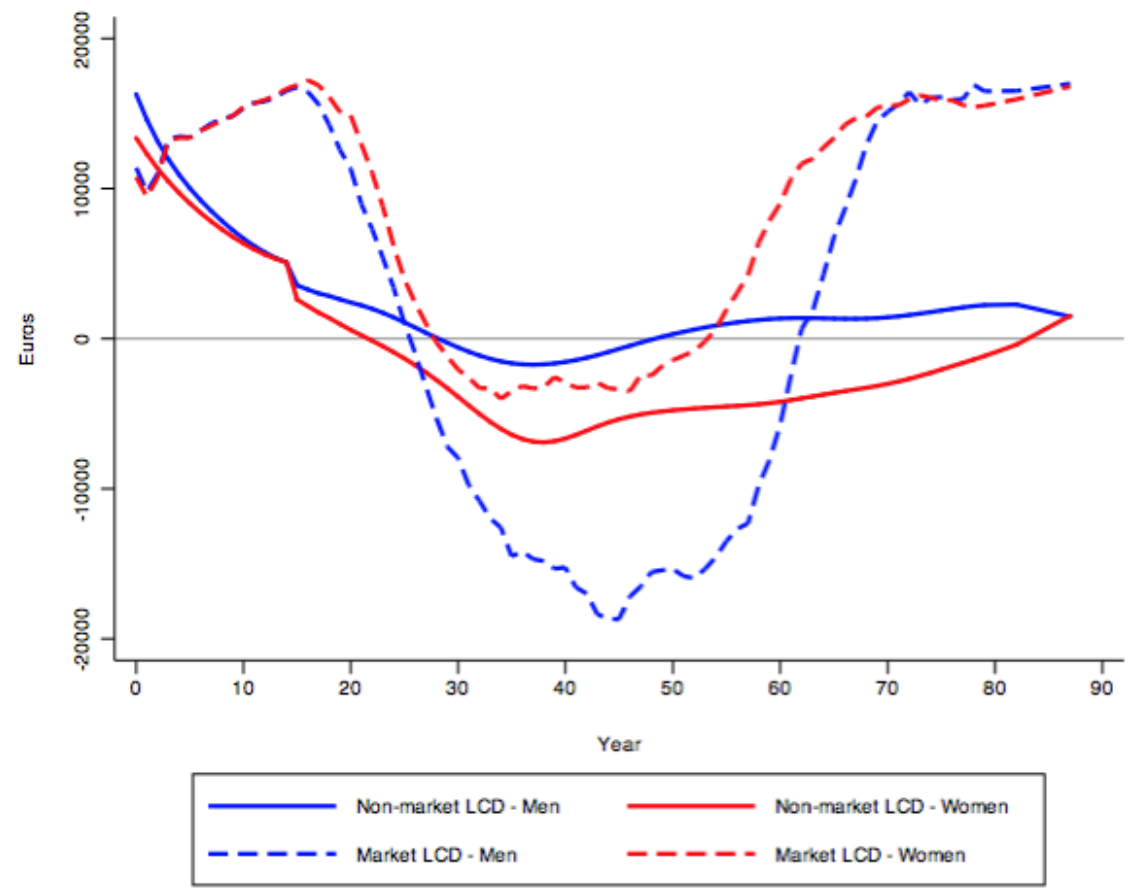

Source: Author's own calculations.

Figure 3 shows distribution of net public and private transfers per capita including market and non-market accounts - by age group and gender. Among 
children, transfers and age reallocations are not very different by gender. For children under 12 , time transfers represent from $60 \%$ to $24 \%$ of their total LCD, decreasing with age, while public transfers increase. Between ages 0 and 3, boys receive more public and private transfers, and especially more time than girls, similarly to the findings of Donehower and Mejía (2012) and Dukhovnov and Zagheni (2015) for the US. This might be due to the fact that families spend more time with the firstborn child (Price 2008) as they do not have to share with other children, together with the fact that more boys than girls are born - in Spain the sex ratio at birth was 106 boys per 100 girls in 2009. Furthermore, despite the decrease in differences in male and female infant mortality, health expenditure is still higher for male children (Ahn, Meseguer, and Herce San Miguel 2003) and this could also imply extra care time.

Figure 3: Net time (non-market) and money (market: public and private) transfers financing the LCD by gender and age (per capita)

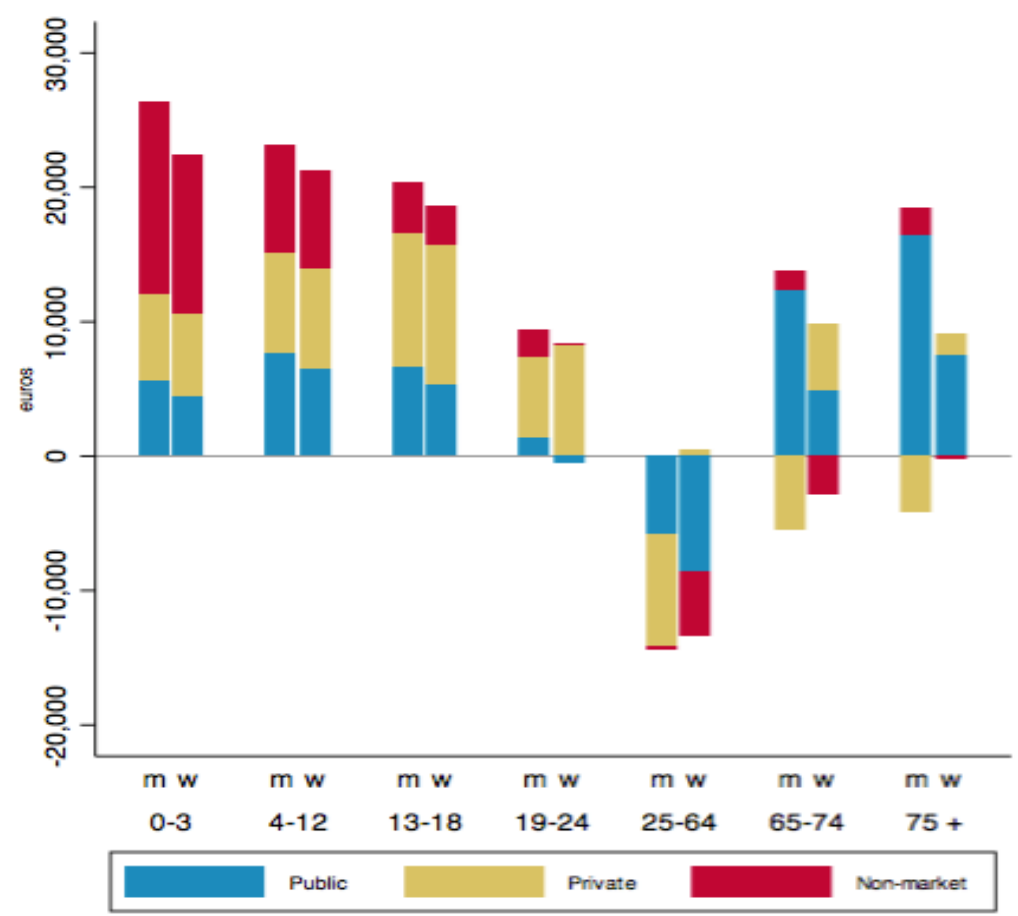

Source: Author's own calculations. 
Over working ages (25-64) and also for ages 65-74, women are net private transfer recipients while men are net donors. Contrarily, women are net givers of time transfers, while men receive these services. As both kinds of transfer occur within the household, this could indicate labour division by gender. Regarding public transfers in the elderly, larger transfers received by men than women are explained by their different retirement benefits, resulting from the higher earnings and employment rates experienced by men.

Figure 4 displays the distribution of household activities received (inflows) divided into care and household work, by recipient age ( $\mathrm{x}$ axis) and donor age (y axis), by gender. We observe that among care activities, age distribution is similar by gender. Care for the elderly is negligible, probably due to a low level of co-residence. Both men and women concentrate their care activities during reproductive ages, before their children become adults. However, the amount of time devoted to these activities is much higher for women at ages around 30.

A very significant life cycle difference in household work distribution of inflows by gender is observed (downward figures). Men participate in housework only during reproductive ages, and their transfers are aimed at children. Contrarily, women provide housework throughout their life. Their peaks are directed toward childbearing ages, and adults of a slightly higher age than themselves, supposedly their partners, especially when recipients are around 55-60 and 75 years old. It is particularly interesting to see that children at ages 13 to 18 are receiving a larger amount of household work transfers than children below this age. 
Figure 4: Distribution of time transfers (in euros) by recipient's age and provider's age and gender

a. Care transfers
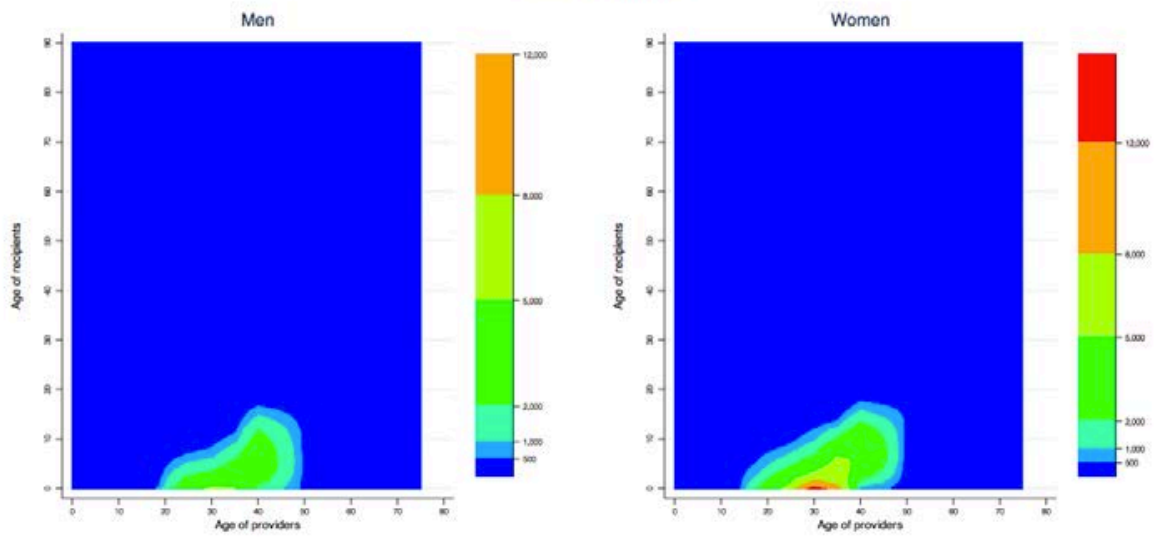

b. Household work transfers
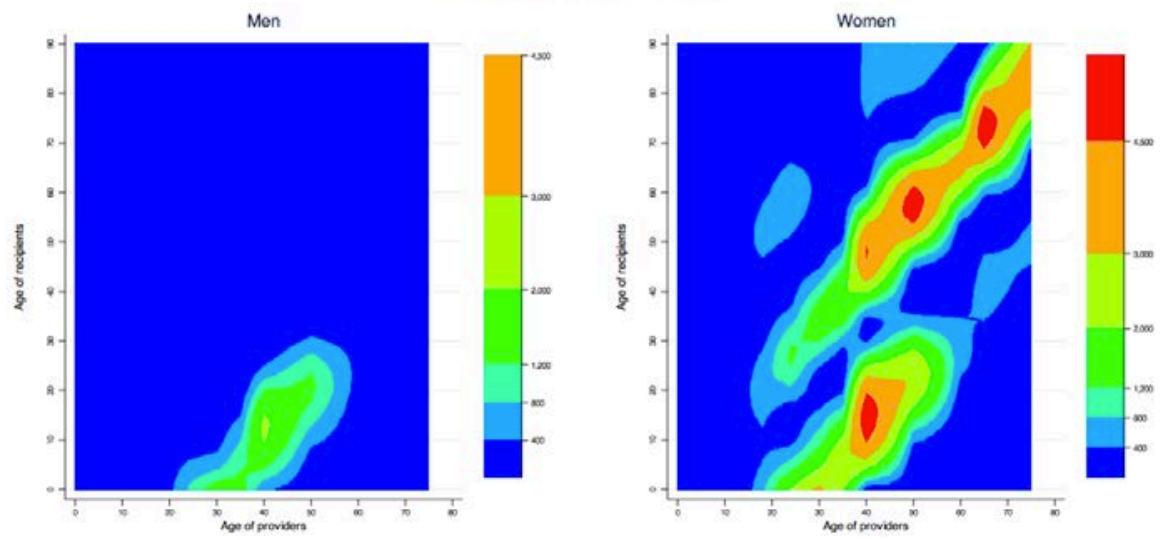

*Data plotted in the $y$-axis refer to the age of both sexes' recipients.

Source: Authors' calculations using TUS (2009-2010). 


\section{Conclusion}

Our study quantifies differences between paid work and domestic unpaid work by gender in Spain, contributing to the measurement of women's work within the household, which is critical for a thorough account of intergenerational transfers. Introducing gender and non-market activities into the transfer study reveals a significant change in women's capacity to finance life cycle deficit and challenges the meaning of economic dependency, which usually only considers paid activities.

The analysis of time transfers by age reveals that care and housework transfers are particularly intensive for children under 12. Men of all ages are net housework transfer receivers. Moreover, women are the main time donors throughout their adult life, and men only contribute to care activities when there are small children in the household, which could be a new feature of younger generations. The results shown are affected by the fact that Spain is still experiencing female incorporation into the labour market and further investigation is needed in this respect. Moreover, it remains unclear how the current economic crisis has impacted gender roles in time production, as it is currently challenging the dual-earner model in precarious households (Vidal and Vono 2015) and reconfiguring public and private transfers (Naldini and Jurado 2013). Additionally, elderly-care time profiles could be improved using better information to capture interhousehold time transfers, and general time-use results are affected by the method employed to value time or the fact that we are not considering the possibility of multitasking.

Our results highlight the importance of time transfers over the life cycle in Spain, basically those of adult women who are less present in market activities. While men provide care and some housework only when they have young children, women provide both to other household members during their entire lives, independently of the age of the other member. Therefore, there is a need to stimulate policies to reduce work-family balance costs for women who either increment their labour journey with time production or are left outside the protection of the paid labour market.

\section{Acknowledgements}

The authors thank Gretchen Donehower for her help in applying the methods. Comments from two anonymous reviewers contributed to improve an earlier version of this manuscript. This research received institutional support from the Spanish Science and Technology System (Project numbers ECO2015-67999-R, ECO2015-71981REDT, ECO2012-35054 and CSO2013-48042-R), the Catalan Government Science Network (Project number SGR2014-1257), from XREPP - Xarxa de Referència en 
Rentería et al.: Intergenerational money and time transfers by gender in Spain

$\mathrm{R}+\mathrm{D}+\mathrm{I}$ en Economia e Polítiques Públiques (XREPP) of Catalan Government, from the Red de excelencia SIMBIEN ECO2015-71981-REDT, the Agaur grant number FIDGR 2013, and the European Commission through the AGENTA project (grant agreement no: 613247). 


\section{References}

Ahn, N., Meseguer, J.A., and Herce San Miguel, J.A. (2003). Gasto Sanitatio y envejecimiento de la población en España. Documentos de Trabajo 7. Fundación BBVA.

Abraham, K.G. and Mackie, C. (2005). Beyond the market: Designing nonmarket accounts for the United States. Washington, DC: National Academies Press.

Albertini, M., Kohli, M., and Vogel, C. (2008). Intergenerational transfers of time and money in European families: common patterns - different regimes? Journal of European Social Policy 17(4): 319-334. doi:10.1177/0958928707081068.

Anxo, D., Flood, L., Mencarini, L., Pailh, A., Solaz, A., and Tanturri, M.L. (2007). Gender differences in time use over the life course in France, Italy, Sweden, and the US. Feminist Economics 17(3): 159-195. doi:10.1080/13545701.2011. 582822 .

Brines, J. (1994). Economic Dependency, Gender, and the Division of Labor at Home. American Journal of Sociology 100(3): 652-688. doi:10.1086/230577.

Chadeau, A. (1992). What is Households' non-market production worth? OECD Economic Studies 18(spring).

Donehower, G. (2014) Incorporating Gender and Time Use into NTA: Estimating NTA and National Time Transfer Accounts by Sex. http://www.ntaccounts.org/web/ nta/show/Gender,\%20Time\%20use.

Donehower, G. and Mejia-Guevara, I. (2012). Everybody works: gender, age and economic activity. Paper presented at the 2012 Meeting of the Population Association of America, San Francisco, Population Association of America, San Francisco, May 3-5.

Dukhovnov, D. and Zagheni, E. (2015) Who Takes Care of Whom in the US? Evidence from Matrices of Time Transfers by Age and Sex. Population and Development Review 41(2): 183-206. doi:10.1111/j.1728-4457.2015.00044.x.

Durán, M.A. (2010). Tiempo de vida y tiempo de trabajo. Bilbao: Fundación BBVA: 192. http://www.fbbva.es/TLFU/dat/DE_2010_tiempo_vida.pdf.

Durán, M.A. (2012). El trabajo no remunerado en la economía global. Bilbao: Fundación BBVA: 507. http://www.fbbva.es/TLFU/dat/DE_2012_trabajo_no_ remunerado.pdf. 
Encuesta anual de estructura salarial (EAES) (2009). Instituto Nacional de Estadística. http://www.ine.es.

Encuesta de Presupuestos familiares (EPF) (2009). Instituto Nacional de Estadística [electronic resource]. http://www.ine.es.

Encuesta de Uso del Tiempo (2009-2010). Available at http://www.ine.es.

Esping-Andersen, G. (1999). Social Foundations of Post-industrial Economies. New York: Oxford University Press. doi:10.1093/0198742002.001.0001.

EU Statistics on Income and Living Conditions (EU-SILC) (2010). Eurostat.

Ferrera, M. (1996). The 'Southern Model' of Welfare in Social Europe. Journal of European Social Policy 6(1): 17-37. doi:10.1177/095892879600600102.

Folbre, N. (2004). Family Time: The Social Organization of Care. New York: Routledge.

Gál, R., Szabóc, E., and Vargha, L. (2015). The age-profile of invisible transfers: The true size of asymmetry in inter-age reallocations. The Journal of the Economics of Ageing 5: 98-104. doi:10.1016/j.jeoa.2014.09.010.

Gimenez-Nadal, J.I. and Sevilla A. (2014). Total work time in Spain: evidence from time diary data. Applied Economics 46(16): 1894-1909. doi:10.1080/00036846. 2014.887194.

Giullari, S. and Lewis, J. (2005). The adult worker model family, gender equality and care: The search for new policy principles and the possibilities and problems of a capabilities approach. Economy and Society 34(1): 76-104. doi:10.1080/030851 4042000329342.

Hammer, B., Prskawetz, A., and Freund, I. (2015). Production activities and economic dependency by age and gender in Europe: A cross-country comparison. The Journal of the Economics of Ageing 5: 86-97. doi:10.1016/j.jeoa.2014.09.007.

Instituto Nacional de Estadística (INE). Contabilidad Nacional de España. Base 2008 [electronic resource].

Jimenez-Fontana, P. (2015). Analysis of non-remunerated production in Costa Rica. The Journal of the Economics of Ageing 5: 45-53. doi:10.1016/j.jeoa.2014. 09.004.

Kluge, F.A. (2014). The Economic Lifecycle by Gender - Results Combining Monetary and Time Use Estimates Comparative. Population Studies 39(4): 707-726. 
Lee, Y.J., Parish, W.L., and Willis, R.J. (1994). Sons, daughters and intergenerational support in Taiwan. American Journal of Sociology 94: 1010-1041. doi:10.1086/ 230370.

Lee, R. and Mason, A. (2011). Population Aging and the Generational Economy. A Global Perspective. Northampton, Massachusetts: Edward Elgar Publishing. doi:10.4337/9780857930583.

Lewis, J. (2009). Work-family balance, gender and policy. Cheltenham, UK: Edward Elgar. doi:10.4337/9781848447400.

Ministerio de educación, cultura y deporte (MECD). www.mecd.gob.es.

Ministerio de Sanidad, Servicios Sociales y Igualdad (MSSSI). www.msssi.gob.es.

Naldini, M. and Jurado, T. (2013). Family and welfare state reorientation in Spain and inertia in Italy from a European perspective. Population Review 52(1): 43-61.

Nieuwenhuis, R., Need, A., and Van der Kolk, H. (2012). Institutional and Demographic Explanations of Women's Employment in 18 OECD Countries, 1975-1999. Journal of Marriage and Family 74(3): 614-630. doi:10.1111/j. 1741-3737.2012.00965.x.

Patxot, C., Rentería, E., Sánchez-Romero, M., and Souto, G. (2011). How intergenerational transfers finance the lifecycle deficit in Spain. In: Lee, R. and Mason, A. (eds.). Population Aging and the Generational Economy: A Global Perspective. doi:10.4337/9780857930583.00019.

Price, J. (2008). Parent-Child Quality Time: Does Birth Order Matter? Journal of Human Resources 43(1): 240-265. doi:10.3368/jhr.43.1.240.

Reid, M. (1934). Economics of Household Production. New York: John Wiley.

Saraceno, C. (1997). Family change, family policy and the restructuring of welfare. In: OECD (ed.). Family, Market and Community: Equity and Efficiency in Social Policy. Paris: OECD: 81-100.

United Nations (UN) (2013). National Transfer Accounts Manual. Measuring and Analysing the Generational Economy. New York: United Nations Publication, Population Division, Department of Economic and Social Affairs.

Vidal, E. and Vono, D. (2015). Entrapped as Domestic Workers? The Effect of Economic Context on Work Opportunities. In: Domingo, A., Sabater, A., and Verdugo, R.R. (eds.). Demographic Analysis of Latin American Immigrants in Spain. From Boom to Bust. Springer. 
Rentería et al.: Intergenerational money and time transfers by gender in Spain

Waring, M. (1999). Counting for nothing: what men value and what women are worth. University of Toronto Press.

Willis, R.J. (1988). A theory of the equilibrium rate of interest: Life cycles, institutions and population growth. In: Lee, R.D., Arthur, W.B., and Rodgers, G. (eds.). Economic Consequences of Alternative Population Patterns. Oxford: Oxford University Press: $106-138$.

Zagheni, E. and Zannella, M. (2013). The life-cycle dimension of time transfers in Europe. Demographic Research 29(35): 937-948. doi:10.4054/DemRes.2013. 29.35.

Zagheni, E., Zannella, M., Movsesyan, G., and Wagner, B. (2015). A comparative analysis of European time transfers between generations and genders. Springer. doi:10.1007/978-94-017-9591-3.

Zannella, M. (2014). Reallocation of resources between generations and genders in the market and non-market economy. The case of Italy. The Journal of the Economics of Ageing 5: 33-44. doi:10.1016/j.jeoa.2014.09.003. 